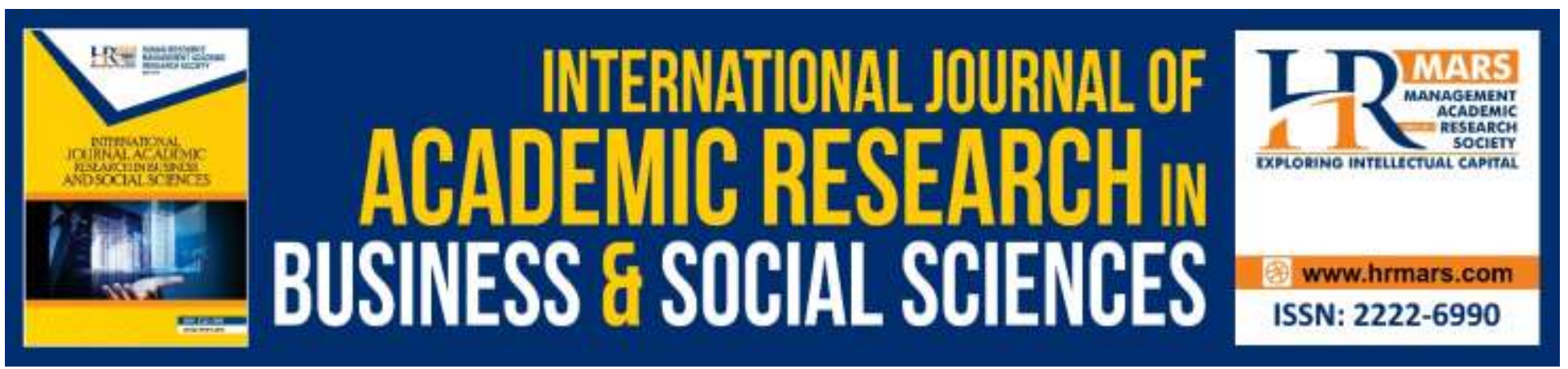

\title{
Investigating the Quality of Banking Services: Evidence from Jordanian Commercial Banks
}

Eyad M. Malkawi, Mohamed Ibrahim Mugableh, Jumah M. Abbad

To Link this Article: http://dx.doi.org/10.6007/IJARBSS/v10-i1/6846

DOI:10.6007/IJARBSS/v10-i1/6846

Received: 22 December 2019, Revised: 31 December 2019, Accepted: 01 January 2020

Published Online: 29 January 2020

In-Text Citation: (Malkawi et al., 2020)

To Cite this Article: Malkawi, E. M., Mugableh, M. I., \& Abbad, J. M. (2020). Investigating the Quality of Banking Services: Evidence from Jordanian Commercial Banks. International Journal of Academic Research in

Business and Social Sciences, 10(1), 224-231.

Copyright: () 2020 The Author(s)

Published by Human Resource Management Academic Research Society (www.hrmars.com)

This article is published under the Creative Commons Attribution (CC BY 4.0) license. Anyone may reproduce, distribute, translate and create derivative works of this article (for both commercial and non-commercial purposes), subject to full attribution to the original publication and authors. The full terms of this license may be seen

at: $\underline{\text { http://creativecommons.org/licences/by/4.0/legalcode }}$

Vol. 10, No. 1, 2020, Pg. 224 - 231

http://hrmars.com/index.php/pages/detail/IJARBSS

JOURNAL HOMEPAGE

Full Terms \& Conditions of access and use can be found at

http://hrmars.com/index.php/pages/detail/publication-ethics 


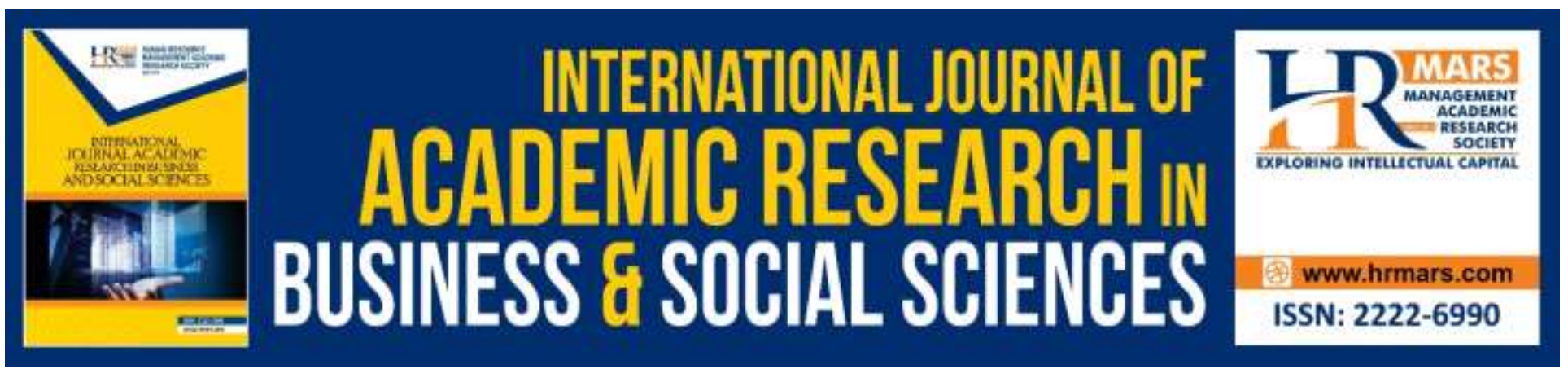

\title{
Investigating the Quality of Banking Services: Evidence from Jordanian Commercial Banks
}

\author{
Eyad M. Malkawi, Mohamed Ibrahim Mugableh \\ Department of Finance and Banking Science, College of Administrative and Financial Sciences, Irbid \\ National University, Jordan. \\ Email:mugableh83@gmail.com
}

Jumah M. Abbad

Financial and Banking Department, Faculty of Finance and Business Administration, Al al-Bayt University, Jordan

\begin{abstract}
The main objective of this study is to measure the quality level of the Jordanian banking services, and to investigate the opinions of the beneficiaries from the quality of Jordanian banking services. However, the services of banks are characterized by their importance in various fields (i.e., economic, social, and civilization). This study is conducted in the Jordanian banking sector, because this sector has a key role in the Jordanian economy. In addition, the challenges are facing banking sector because of the openness, and the possibility of foreign banks entry and what consequent competition.
\end{abstract}

Keywords: Banking, Services, Commercial Banks, Quality, Jordan.

\section{Introduction}

The banking system in Jordan has witnessed many studies examined the services quality which is provided by Jordanian banks in one hand and opinions of the beneficiaries from the quality of these services in the other hand. However, banks are making great efforts to deliver their messages to customers through various communication methods that guarantee the highest degree of persuasion which is based on the provision of high quality services to customers. This is because the customer often assesses banks based on the quality of banking services. The problem of this study can be summarized by answering the following questions:

- What are the services and quality standards that are followed by the Jordanian banks?

- What are the opinions of the beneficiaries from the quality of Jordanian banking services?

The main objective of this study is to investigate the opinions of the beneficiaries from the quality of Jordanian banking services, and the possibility of using services between banks as a competitive 
advantage. The definition for "service" concept is any form of assistance that would make it easier for the consumers to achieve their goals. The American marketing association (AMA) defined it as the benefits and satisfactions which are offered for sale (Jackson et al., 2003; Choudhury, 2008; Cepeda et al., 2015; Kotler et al., 2018).

\section{Theoretical Background}

Marketing concept is dealing with services provided by banks through the essence of service which is a group of utilities. Al-Namer et al. (2002) pointed out that the characteristics of banking services are delivered as follows:

i. (i) Intangibility: which means that the bank's success in settling its services, depends on its capabilities and skills to explain and clarify the advantages and benefits that offered to the customer.

ii. (ii) Inseparability: banking services are focusing on providing their services in the right place and time; therefore, it is necessary that the bank pursues a policy of buying and selling because it is considered the best way for banking services marketing.

iii. (iii) Lack of special identity: for customers, the services offered by banks are similar, because the customer is dealing with a particular bank.

iv. Wide range of services: the banks faces requests and needs of different institutions, whether industrial or services, so the bank needs more than a marketing mix to meet the needs of various customers sectors.

v. Geographical dispersion: to achieve a great success for the bank, it should be able to reach customers everywhere, so it has to owned integrated subsidiaries that geographically dispersed to suit the customers' needs.

vi. Growth must be balanced with risk: when banks sell loans, it will be at risk. Therefore it is necessary to find a balance between growth and activity and the degree of risk.

vii. Credit Responsibility: the protection of customers' deposits.

viii. Higher adapt of marketing system.

ix. The intensity of work: banking is a high intensity factor, which increases the cost of production and affects the price of products.

x. Fluctuations in demand: fluctuations may occur at the request of certain varieties of services for emergency reasons or seasonal conditions such as, the demand for loans for tourism projects for agricultural credit in certain reasons. That's, what resulting a significant pressure on the functions of the banking marketing.

Bapat (2014) determined the five factors affecting the marketing of banking services. These factors are change in customer behavior; competition; technology innovation; customer relations and quality; lack of laws and government interventions. The quality according to the American society for quality (ASQ) was defined as the characteristics of a product or service that bear on its ability to satisfy stated or implies needs. In addition, quality is considered as a way to support the competition, and it's the marketing strategy for banking services maker. So the quality of service is the main objective of the bank, because it is considered a critical point for the bank's success or failure (Corneliu, 2013; Goyal \& Chanda, 2017; Fernandes \& Pinto, 2019; Alevriadou, 2016, Wicaksana \& Asandimitra (2018) 
Salleh, Jusoh, Embong, \& Mamat (2018). Thus, research has revealed that the high quality services are the major cause of achieving profits and minimize costs.

Al-Habil et al. (2017) found that the quality of services has two main elements (i.e., technical quality and functional quality). So the department of banking services has three main questions that should be asked in order to evaluate its' services. - Did the customer get the requiring service? - How long the customer spent time? - Did the customer satisfied with the service?

\section{Methodology and Results Analysis}

This study employs the interview technique for a sample of beneficiaries of banking services to determine their opinions about the quality of services at Jordanian banks. However, several questions have been asked as the following:

Q1. Do you deal with banks and take benefits from its services? The answers in Table (1)

Table (1)

\begin{tabular}{|c|c|c|}
\hline The answer scale & Frequencies & $\%$ \\
\hline Yes & 148 & 56.06 \\
\hline No & 116 & 43.94 \\
\hline Total & 264 & 100 \\
\hline
\end{tabular}

Q2. Do you deal with the Arab or foreign banks? The answers in Table (2)

Table (2)

\begin{tabular}{|l|c|c|}
\hline The answer scale & Frequencies & $\%$ \\
\hline deal with the Arab banks & 163 & 88.58 \\
\hline deal with foreign banks & 21 & 11.41 \\
\hline Total & 184 & 100 \\
\hline
\end{tabular}

It is noted from Table (2) that there is a high turnout for the Jordanians on the Jordanian banks. Q3. Do Jordanian banks offering a high quality services as in the foreign banks in the Jordan's market? The answers in Table (3)

Table (3)

\begin{tabular}{|l|c|c|}
\hline The answer scale & Frequencies & $\%$ \\
\hline Very similar & 23 & 14.11 \\
\hline similar & 41 & 25.15 \\
\hline Similar to a certain extent & 55 & 33.74 \\
\hline unlike & 29 & 17.79 \\
\hline Not quite similar & 15 & 9.20 \\
\hline Total & 163 & 100 \\
\hline
\end{tabular}

It is noted from Table (3) that $39.26 \%$ of customers believe that the services of Jordanian banks are similar or very similar to those provided by foreign banks. While $33.74 \%$ of respondents believed that 
the services are similar to a certain extent. Furthermore, $27 \%$ of respondents believed that the services of Jordanians banks are not quite similar to those provided by foreign banks.

Q4. Do the Jordanian banks characterized by accuracy in its dealings, and make statements? The answers in Table (4)

Table (4)

\begin{tabular}{|l|c|c|}
\hline The answer scale & Frequencies & $\%$ \\
\hline Very accurate & 76 & 43.93 \\
\hline accurate & 33 & 19.08 \\
\hline Accurate to some extent & 40 & 23.12 \\
\hline Inaccurate & 17 & 9.83 \\
\hline Not very accurate & 7 & 4.05 \\
\hline Total & 173 & 100 \\
\hline
\end{tabular}

It is noted from Table (4) that $63.01 \%$ of customers believe that the services of Jordan's banks are accurate in its dealings, and make statements, while $13.88 \%$ of these banks are inaccurate.

Q5.Do Jordanians banks offer their services on time and care about customers' needs? The answers in Table (5)

Table (5)

\begin{tabular}{|l|c|c|}
\hline The answer scale & Frequencies & $\%$ \\
\hline Totally agree & 103 & 63.19 \\
\hline Agree & 40 & 24.54 \\
\hline Neutral & 15 & 9.20 \\
\hline disagree & 3 & 1.84 \\
\hline Totally disagree & 2 & 1.22 \\
\hline Total & 163 & 100 \\
\hline
\end{tabular}

It is noted from Table (5) that the majority of customers agree that Jordanians banks offer their services on time and care about customers needs.

Q6. Do the staff of Jordanians banks are characterized by required skills to provide the banking services? The answers in Table (6)

Table (6)

\begin{tabular}{|l|c|c|}
\hline The answer scale & Frequencies & $\%$ \\
\hline Totally agree & 17 & 10.43 \\
\hline Agree & 37 & 22.70 \\
\hline Neutral & 52 & 31.90 \\
\hline disagree & 40 & 24.54 \\
\hline Totally disagree & 17 & 10.43 \\
\hline Total & 163 & 100 \\
\hline
\end{tabular}


Table (6) referred to mixed views; where $33.13 \%$ believed that the staff of Jordanians banks is characterized by the required skills to provide the banking services. While $31.90 \%$ take a neutral stance. Furthermore, $34.97 \%$ confirmed that the staff in these banks does not have the required skills. Q7. Does the bank officials characterized by high skills and can easily communicate with customers? The answers in Table (7)

Table (7)

\begin{tabular}{|l|c|c|}
\hline The answer scale & Frequencies & $\%$ \\
\hline Totally agree & 21 & 10.42 \\
\hline Agree & 86 & 22.70 \\
\hline Neutral & 32 & 31.90 \\
\hline Disagree & 27 & 24.53 \\
\hline Totally disagree & 17 & 10.42 \\
\hline Total & 163 & 100 \\
\hline
\end{tabular}

It is noted from Table (7) that most of customers are agree that bank officials characterized by high skills and can easily communicate with them.

Q8. Are automatic transfer machines (ATM) providing the necessary services with high quality? The answers in Table (8)

Table (8)

\begin{tabular}{|l|c|c|}
\hline The answer scale & Frequencies & $\%$ \\
\hline Totally agree & 24 & 14.72 \\
\hline Agree & 71 & 43.55 \\
\hline Neutral & 50 & 30.67 \\
\hline Disagree & 18 & 11.04 \\
\hline Totally disagree & 0 & 0 \\
\hline Total & 163 & 100 \\
\hline
\end{tabular}

It is noted from Table (8) that $58.27 \%$ believed that ATM provides the necessary services with high quality. While (11.04\%) are disagree. In addition, $30.67 \%$ are neutral.

Q9. Does the bank have subsidiaries in the kingdom which is contributed to provide the services? The answers in Table (9)

Table (9)

\begin{tabular}{|l|c|c|}
\hline The answer scale & Frequencies & $\%$ \\
\hline Totally agree & 18 & 11.04 \\
\hline Agree & 89 & 54.60 \\
\hline Neutral & 38 & 23.31 \\
\hline Disagree & 10 & 6.13 \\
\hline Totally disagree & 8 & 4.90 \\
\hline Total & 163 & 100 \\
\hline
\end{tabular}


INTERNATIONAL JOURNAL OF ACADEMIC RESEARCH IN BUSINESS AND SOCIAL SCIENCES

Vol. 10, No. 1, Jan, 2020, E-ISSN: 2222-6990 C 2020 HRMARS

It is noted from Table (9) that most of customers are agree that the bank has subsidiaries in the kingdom which is contributed to provide the service, accounted for (65.64\%). While $11.03 \%$ are disagree.

Q10. Does the bank is characterized by a high level of confidentiality in the handling and safety? The answers in Table (9)

Table (10)

\begin{tabular}{|l|c|c|}
\hline The answer scale & Frequencies & $\%$ \\
\hline Totally agree & 46 & 30 \\
\hline Agree & 95 & 62.09 \\
\hline Neutral & 6 & 3.92 \\
\hline disagree & 6 & 3.92 \\
\hline Totally disagree & 0 & 0 \\
\hline Total & 153 & 100 \\
\hline
\end{tabular}

It is noted from Table (10) that most of customers are agree that the bank is characterized by a high level of confidentiality in the handling and safety, accounted for $92.09 \%$.

\section{Conclusions and Recommendations}

The study measures the quality level of the Jordanian banking services, and investigates the opinions of the beneficiaries from the quality of Jordanian banking services. However, the main results show that Jordanian banking services focuses on quality and offers a high quality of services as in the foreign banks in the Jordanian market. In addition, Jordanian banks are characterized by their accuracy in dealing and offering their services on time, and caring about customers' needs. The staff of Jordanians banks also is characterized by required skills to provide the banking services. ATM provides the necessary services with high quality in the Jordanian banks. Given the mentioned results, this study recommends to provide developmental training courses for the staff; in order to improve their skills and to get high quality services.

\section{References}

Al-Habil, W. I., Al-Hila, A. A., Shobaki, M. J., Abu Amuna, Y. M., \& Abu Naser, S. S. (2017). The impact of the quality of banking services on improving the marketing performance of banks in Gaza governorates from the point of view of their employees. International Journal of Engineering and Information Systems, 1(7), 197-217.

Al-Namer, Sadeq, D. S., Al Murad, \& Younis, N. (2002). Marketing of banking services, Aljamieah publishing group, Mousl - Iraq.

Bapat, D. (2014). Marketing of financial services, Biztantra Publications, $1^{\text {st }}$ edition.

Cepeda, I., Leal, A. G., Ortega, J., \& Leal, R. (2015). Linking unlearning with service quality through learning process in the Spanish industry. Journal of Business Research, 68(7), 1450-1457.

Choudhury, K. (2008). Service quality: insights from the Indian banking scenario. Australasian Marketing Journal, 16(1), 48-61. 
Corneliu, B. (2013). The quality of banking services - A basic premise of a bank sustainability. Annals of Faculty of Economics, 1(2), 430-439.

Fernandes, T., \& Pinto, T. (2019). Relationship quality determinants and outcomes in retail banking services: the role of customer experience. Journal of Retailing and Consumer Services, 50, 3041.

Goyal, P., \& Chanda, U. (2017). A Bayesian network model on the association between CSR, perceived service quality and customer loyalty in Indian banking industry. Sustainable Production and Consumption, 10, 50-65.

Jackson, W. E., Nandakumar, P., \& Roth, A. V. (2003). Market structure, consumer banking, and optimal level of service quality. Review of Financial Economics, 12(1), 49-63.

Kotler, P., Keller, K. L., Hoon, A. S., Meng, L. S., \& Tiong, T. C. (2018). Marketing Management: an Asian perspective, $5^{\text {th }}$ edition.

Malkawi, E. M., Mugableh, M. I., \& Abbad, J. M. (2020). Investigating the Quality of Banking Services: Evidence from Jordanian Commercial Banks. International Journal of Academic Research in Business and Social Sciences, 10(1), 209-216.

Wicaksana, S. B., Asandimitra, N. (2018). Halloween Effect in Indonesia Stock Exchange, International Journal of Academic Research in Accounting, Finance and Management Sciences 8 (3): 118127

Salleh, M., Jusoh, A., Embong, R., \& Mamat, M. (2018). Learning Organizational Model in the 21th Century Classroom at Sultan Mahmud Science Secondary School in Terengganu, Malaysia. International Journal of Academic Research in Progressive Education and Development, 7(4), 410-426. 